\title{
Isaac Gondim Filho e Hermilo Borba Filho: diálogos sobre a modernização do teatro pernambucano
}

\section{Luís Augusto da Veiga Pessoa Reis*}

Resumo: Estudo comparativo entre a dramaturgia de Isaac Gondim Filho e as ideias renovadoras de Hermilo Borba Filho, nome central na modernização do teatro pernambucano em meados do século 20. Observam-se, à luz do Regionalismo de Gilberto Freyre, aproximações e distanciamentos entre esses dois dramaturgos que obtiveram reconhecimento, não somente em Pernambuco, mas também em outras regiões do país, contribuindo, cada um a seu modo, para a ampliação do chamado "teatro nordestino".

Palavras-chave: Hermilo Borba Filho. Isaac Gondim Filho. Dramaturgia. Teatro pernambucano.

Abstract: Comparative study between the dramaturgy of Isaac Gondim Filho and the renewing ideas of Hermilo Borba Filho, key name in the modernization of the theater in Pernambuco in the mid-2oth century. In the light of Gilberto Freyre's Regionalism, the article focus on the similarities and the differences between these two playwrights, who obtained recognition, not only in Pernambuco, but also in other regions of the country, contributing, each in their own way, to the expansion of the so-called "teatro nordestino" (northeastern theater).

Keywords: Hermilo Borba Filho. Isaac Gondim Filho. Dramaturgy. Pernambuco theater.

Resumen: Estudio comparativo entre la dramaturgia de Isaac Gondim Filho y las ideas renovadoras de Hermilo Borba Filho, nombre central en la modernización del teatro Pernambuco a mediados del siglo 20. A la luz del Regionalismo de Gilberto Freyre, existen similitudes y distancias entre estos dos dramaturgos que obtuvieron reconocimiento, no solo en Pernambuco, sino también en otras regiones del país, contribuyendo, cada uno a su manera, a la expansión del llamado "teatro nordestino" (teatro del noreste).

Palabras clave: Hermilo Borba Filho. Isaac Gondim Filho. Dramaturgia. Teatro Pernambuco.

\section{Um nome na modernidade teatral do Recife}

Uma apreciação mais atenta da produção de dramaturgos pernambucanos em

\footnotetext{
* Pesquisador e Professor Associado II do Departamento de Artes da UFPE, com pesquisas nas áreas de Dramaturgia, História do Teatro e Pedagogia do Teatro. https://orcid.org/oooo-0002-9206-5084
}

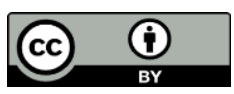


atividade durante a segunda metade do século 20 é capaz de interpelar certo entendimento, um tanto reduzido, ou mesmo enviesado, que por vezes pareceu querer enquadrar o teatro feito em Pernambuco, ou no Nordeste de modo geral, a certos modelos, bem controlados, que supostamente definiriam, ou que reforçariam, uma identidade própria para a expressão teatral de toda essa região, tão vasta e diversificada. Este ensaio, que enfoca as proximidades e os distanciamentos entre o teatro produzido por Isaac Gondim Filho (1925-2003) e as ideias modernizantes defendidas por Hermilo Borba Filho (1917-1976), nome central para a renovação da cena pernambucana no período, busca evidenciar que essas visões um tanto limitadoras do teatro em ssa região, talvez geradas por interpretações insuficientes do Regionalismo de Gilberto Freyre, não parecem encontrar sustentação factual no conjunto da moderna dramaturgia pernambucana.

O próprio Hermilo Borba Filho, que em grande medida processou no âmbito teatral os ideais "Regionalistas-Modernistas-Tradicionalistas" (FREYRE, 1996) do autor de Casa-grande $\mathcal{E}$ senzala, produziu uma dramaturgia marcadamente diversificada, experimentando vários gêneros, formas e conteúdos. Igualmente, o teatro de Ariano Suassuna, cujo sucesso, sobretudo de suas comédias, certamente foi decisivo para a valorização do moderno teatro nordestino, e que paradoxalmente parece ter sido tomado como uma espécie de paradigma quase impositivo para todo o teatro da região, também se revela, se examinado com atenção na coerência de seu projeto estético, livre para se manifestar de maneiras variadas, indo do trágico ao cômico, do dramático ao épico. Luiz Marinho, outro nome de destaque nesse grupo de autores teatrais nordestinos, não foi diferente: criou uma obra ampla e diversa (VIEIRA, 2019), embora tenha ganhado mais notoriedade, assim como Ariano, pelas comédias em que retrata, com algum saudosismo, aspectos pitorescos da vida rural de Pernambuco.

Nesse viés, uma aproximação com a prolífica produção teatral de Isaac Gondim Filho revela-se um auspicioso passo para a expansão do nosso olhar sobre a moderna criação dramatúrgica em Pernambuco. Afinal, esse dramaturgo explorou uma grande variedade de ambientes psicológicos e de contextos sociais, para tratar de questões como: família, amor, preconceitos, sexo, religião, injustiças sociais, amizade, sofrimento, desespero e morte. Joel Pontes, em seu livro Teatro moderno em Pernambuco (1966), 
destaca essa marca do autor:

\begin{abstract}
Isaac Gondim Filho (Recife, PE, 1925) é um desses autores que se fazem dentro das caixas de teatro. Foi ator, é diretor e professor de Interpretação, já manteve conjunto próprio até que, desejoso de ordenar seus conhecimentos, frequentou cursos na Europa: Academia Sílvio D’Amico [Itália] e Teatro Marigny [França]. Tem, sobretudo, a atenção estética voltada para os intérpretes e para o público. Daí preferências estéticas variáveis e peças de circunstância: em sua obra tudo varia, como se fosse um ator a representar diferentes papéis. Essa espécie de instabilidade tem sido a sua estabilidade. Conforme o que a vida lhe esteja sugerindo, escreve peças rurais ou sofisticadas, leva ao palco sertanejos famintos, num tratamento linear de efabulação, ou alegorias ou, ainda, as confissões de membros da alta sociedade, como Priestley, arrancadas por via de um acontecimento misterioso. Todas as técnicas lhe servem, todos os assuntos, como se depois de tanto escrever continuasse a experimentar os próprios recursos (PONTES, 1966, p. 151).
\end{abstract}

Em seguida, nessa apresentação, Joel Pontes lista algumas das peças de Isaac, não se limitando apenas às que haviam sido, até então, publicadas e/ou encenadas, mas mencionando também alguns textos inéditos. Há referências às seguintes obras: Conflito na consciência (1950), A grande estiagem (1953) e A hora marcada (1955), entre as peças publicadas; Recalque (1951), O mundo é pequeno demais (1951), A vida continua amanhã (1952), Uma estrela correu no céu (1953), Senhorzinho de engenho (1954), Meus santos diabinhos (1955), entre as obras que foram encenadas, mas não publicadas; e Revolvendo cinzas (1951), Tara (1952), O fim (1951) e Um aperto de mão (1954), entre os títulos inéditos. Após essa relação, é destacado o reconhecimento artístico angariado por muitas dessas obras:

Na maioria, estas peças foram distinguidas com prêmios - da Academia Brasileira de Letras, Secretaria de Educação de Pernambuco, menções honrosas do concurso "Peças para a juventude" do Ministério da Educação, etc. - e traduzidas para o francês, inglês, alemão, italiano e holandês. A grande estiagem o foi para todas estas línguas, caso só comparável ao do Auto da Compadecida (PONTES, 1966, p. 152).

É oportuno observar que, entre as peças assinaladas por Joel Pontes, não há nenhuma que tenha sido escrita após Isaac retornar de sua estada na Europa, onde por três anos, de 1957 a 1959, teve a chance de estudar em prestigiosas instituições dentro do 
universo da cultura teatral ${ }^{1}$, e onde certamente pôde atualizar o seu olhar de espectador, assistindo a espetáculos de grandes encenadores franceses, italianos e ingleses.

De fato, Isaac passou a escrever com menos intensidade a partir da década de 1960. Decerto, o aprofundamento de seus conhecimentos teatrais, bem como a provável limitação de tempo imposta pelas obrigações de professor do Curso de Teatro da Escola de Belas Artes (contratado a partir de abril de 1960), em paralelo com as novas demandas de pai de família (casa-se em 1961), impunham-lhe uma necessária redução no ritmo de sua atividade como dramaturgo. Mais adiante, sobretudo nas décadas de 1970 e de 1980, ele volta a produzir vários textos teatrais; agora, porém, com uma característica predominante: trata-se, na maioria, de peças com temas religiosos, muitas vezes reinterpretando cenicamente passagens bíblicas. $\mathrm{O}$ catolicismo, que na juventude o havia conduzido à formação quase completa como monge beneditino, reaparece com força na maturidade, por meio de ações teatrais, quando ele próprio encena, em ocasiões ligadas à Igreja, seus textos de franca inspiração apostólica. Culminando tal esforço criativo, Isaac Gondim Filho publica, em 1982, O drama do evangelho, pela Editora Vozes, prefaciado por Dom Helder Câmara. Nessa obra, espécie de reinvenção ampliada de vários de seus textos apostólicos, Isaac se propõe a reviver teatralmente os fatos narrados pelos evangelistas, oferecendo, na introdução do livro, toda uma metodologia, pedagógico-catequética, a ser desenvolvida por meio da arte dramática.

Desde seus passos iniciais no teatro recifense, ainda bem jovem, Isaac despertou atenção dos intelectuais e dos criadores ligados às artes cênicas em Pernambuco. Um dos primeiros a se manifestar em público a seu respeito foi justamente Hermilo Borba Filho que, em sua coluna no jornal Folha da Manhã, no dia 25 de julho de 1950, comemora a estreia de Isaac como crítico teatral do Jornal do Commercio, destacando a cultura, a sensibilidade e a capacidade realizadora do novo comentarista teatral.

Saudamos o sr. Isaac Gondim Filho e desejamos que ele trabalhe pela crítica com o mesmo entusiasmo demonstrado à frente do Teatro Experimental do Recife. Ninguém desconhece a paixão que anima o jovem dramaturgo em

\footnotetext{
'Entre 1957 e 58, estudou direção teatral, na Academia Nazionale D’Arte Dramatica, de Silvio D’Amico, em Rome; no mesmo período, na mesma cidade, teve aulas de "educação da voz", no Centro Ortofônico La Parola; entre 1958 e 59, fez curso de condicionamento de personagem no Thêàtre Marigny, em Paris; e, ainda em 1959, estudou "playwriting” no London Country Council, em Londres.
} 
relação às coisas do teatro no Recife. Ele está apto a prestar os maiores favores ao nosso movimento cênico, honesto como é, interessado em tudo quanto se relacione com atores, palco, cenários, peças. Sei que possui uma regular biblioteca e - o que é mais importante - lê constantemente os livros, procurando alargar os seus conhecimentos no ramo, aliando assim cultura especializada à sua natural vocação de homem de teatro (BORBA FILHO in Folha da Manhã , 25/7/1950).

Talvez, pressentindo que encontrara, em Isaac Gondim Filho, um aliado em sua luta por um novo teatro no Recife, por um teatro de arte, e não apenas de entretenimento, Hermilo mostra aos seus leitores a relevância das primeiras conquistas obtidas por Isaac nesse campo: "De uma só vez, o sr. Isaac Gondim Filho conseguiu duas coisas importantes no teatro: lançou sua peça 'Conflito na consciência' e criou uma coluna diária de crítica" (BORBA FILHO in Folha da Manhã, 25/7/1950).

Tratava-se da busca por um teatro renovado, livre das marcas formais da cena do século XIX: um teatro em sintonia com as novidades que não paravam de chegar da Europa e dos Estados Unidos, mas também um teatro capaz de ecoar os princípios do Regionalismo de Gilberto Freyre: um teatro feito por gente da terra, tratando de temas e de valores da região, tentando descobrir expressões dramáticas originais, modernas, mas geradas a partir das tradições, das raízes, regionais. Não era outro o esforço de Hermilo à frente do Teatro de Estudante de Pernambuco - TEP, desde 1946. Foi no embalo dessa determinação que vieram à cena, ainda na década de 1940, dramaturgos como Ariano Suassuna, Aristóteles Soares, José Carlos Cavalcanti Borges e José de Moraes Pinho; e, um pouco mais adiante, Luiz Marinho, Jairo Lima, Benjamim Santos, Osman Lins, Vital Santos e Aldomar Conrado, entre outros. Embora não fizesse parte do círculo estrito do TEP, como também não o fazia Aristóteles Soares, Isaac Gondim Filho seguramente recebeu grande influência dessa movimentação em prol de uma nova dramaturgia nordestina.

Não por acaso, uma das primeiras apreciações críticas de A grande estiagem (1953), decerto a peça mais conhecida e premiada de Isaac, foi assinada exatamente por Gilberto Freyre. No Diário de Pernambuco do dia 30 de agosto de 1953, lamentando o estágio ainda pouco desenvolvido do drama nacional, e destacando o significado dessa arte, como indício prioritário do desenvolvimento cultural de uma nação, o sociólogo elogia a composição do jovem dramaturgo recifense, situando-o ao lado de nomes consagrados, 
como os de Rachel de Queiroz e de Nelson Rodrigues, na urgente busca pelo aprimoramento do teatro brasileiro. Destaca a pungência com que Isaac retrata o sofrimento infligido aos sertanejos nordestinos pela seca, mas faz ressalvas à preocupação, talvez excessiva, com o realismo do relato, o que teria inibido, segundo sua apreciação, uma expressão poética mais simbólica, mais transcendente. Reconhece, no entanto, de modo inequívoco, as qualidades do autor, antevendo que essa peça despertaria interesse de outros centros teatrais, como de fato aconteceu:

Trata-se [A grande estiagem], entretanto, de uma afirmação de sensibilidade dramática capaz de atrair para o jovem autor atenções brasileiras, além das pernambucanas. Já conhecido o sr. Isaac Gondim Filho por seus brilhantes experimentos da literatura dramática, sua nova criação dramática talvez o torne conhecido no Rio e em São Paulo, como um dos melhores talentos dos novos do Recife que se vêm especializando em escrever para teatro com seriedade e consciência (FREYRE in Diario de Pernambuco, 30/8/1953).

Nessa observação de Gilberto Freyre pode-se ler a inescapável tensão gerada pela dialética margem-centro, província-metrópole, problema inscrito no próprio cerne do seu movimento Regionalista: a quase aporética situação em que se veem as culturas periféricas, lutando por reconhecimento - e por autorreconhecimento -, tentando processar as novidades que lhes chegam de fora, ao passo que se esforçam para se manter ligadas às suas tradições originais.

Desse modo, portanto, estudar a moderna literatura dramática de Pernambuco, e do Nordeste, significa, antes de tudo, observar a forma como cada autor encarou essa condição, certamente incômoda, de uma dupla presunção de inferioridade: em relação à Europa, berço da modernidade teatral, e em relação aos centros culturais mais desenvolvidos do país, no caso, especialmente no que diz respeito à atividade teatral, Rio de Janeiro e São Paulo, onde supostamente o novo teatro europeu primeiramente deveria ser (re)interpretado. Tal problemática assume especial relevo na trajetória artística do recifense Isaac Gondim Filho, autor fortemente sintonizado com o teatro europeu, mas que soube, dentro dos seus limites, lançar as particularidades do seu olhar sobre questões da sua terra, da sua região, criando peças urbanas e rurais, com personagens de diferentes classes sociais. 


\section{Isaac e Hermilo: aproximações e distanciamentos}

Nesta breve apreciação comparativa, entre o fazer teatral de Isaac Gondim Filho e os ideais que nortearam a ação renovadora de Hermilo Borba Filho na cena pernambucana, estruturaremos nossa observação em três eixos, a ver:

\subsection{Novidade e tradição, amadorismo e profissionalismo}

Em grande medida, como nos mostram os trabalhos de importantes historiadores do teatro nacional (BRANDÃO, 2009; PRADO, 1996; FARIA, 2013; MILARÉ, 2009), a modernização dos palcos brasileiros foi majoritariamente suscitada pela ação de grupos amadores. Cabia a esses conjuntos, menos dependentes de uma resposta positiva nas bilheterias, a missão de inovar, de correr riscos, trazendo aos públicos nacionais as tendências que já há décadas modificavam o teatro nas grandes cidades europeias e norte-americanas. Especificamente, cabia aos amadores apresentar ao Brasil a figura do encenador, cuja ação autoral, como criador do espetáculo, é a própria essência, ou principal traço distintivo, daquilo que se costuma chamar de "teatro moderno" no âmbito dos estudos teatrais.

Enquanto as companhias profissionais, na maior parte das vezes, seguiam tentando estender ao máximo o apogeu do teatro de entretenimento, vivido certamente entre as últimas décadas do século 19 e as três primeiras do século 20, em peças, quase sempre comédias, ou às vezes enfáticos dramalhões, que repetiam, com leve variações, fórmulas já conhecidas e aprovadas pelo grosso dos espectadores, confiando primordialmente no carisma das estrelas que estampavam os cartazes de cada produção, alguns conjuntos de amadores, conhecedores da cena europeia, investiam na busca por um teatro de arte, bem cuidado, com profundidade filosófica e com rigor conceitual na poética levada ao palco; enfim, um teatro moderno, regido pela lógica da encenação, em que todos os elementos da cena - do texto ao cenário, da luz ao figurino, da música à coreografia - deveriam se harmonizar em prol da materialização de um conceito artístico 
assinado pelo encenador.

Nesse panorama, era natural que jovens intelectuais, como Hermilo e Isaac, renegassem o "velho" teatro, com suas cansadas marcas do passado: a caixa do ponto, as luzes de ribalta, os protagonistas exibindo-se no proscénio, os telões pintados ao fundo etc. E isso, naturalmente, aconteceu, pelo menos em certa medida. Porém, diferentemente de outros jovens renovadores da cena nacional, Hermilo e Isaac não embarcaram no discurso de "terra arrasada", renegando por completo toda a tradição da atividade teatral no país. Se, sem dúvida, suas peças, na forma e no conteúdo, já não se enquadravam tranquilamente no velho esquema do teatro mais comercial, impondo um estranhamento ao espectador de então, eles, entretanto, não menosprezaram os experientes artistas dos palcos nacionais, nem se recusaram, eventualmente, a dialogar com a dinâmica dessa velha escola.

Enquanto muitos dos amadores, calcados num ostensivo verniz intelectual, não se cansavam de tentar expor a mediocridade, senão o ridículo, dos velhos e consagrados artistas profissionais, Hermilo - este sem dúvidas um verdadeiro intelectual do teatro veio a público, repetidas vezes, reconhecer $\mathrm{o}$ valor de atores-empresários pernambucanos como Barreto Júnior e Elpídio Câmara (REIS, 2009). Mais tarde, nos anos de 1950, morando em São Paulo, trabalhou com Dercy Gonçalves, atuando como encenador, tendo obtido grande sucesso de público. E, de certo modo, chocando a juventude renovadora do teatro, ele fazia questão de afirmar que aquela atriz, fruto da tradição do teatro de revista, do "teatro rebolado", era uma artista brasileira absolutamente genial, que muito tinha a ensinar aos que se colocavam, então, como os profetas de um teatro realmente artístico no país.

Isaac, por sua vez, teve peças suas montadas por companhias praticantes desse velho teatro mais comercial, como o "drama" Recalque, de 1951, que rodou o Brasil, com muito sucesso, produzido pela atriz Iracema de Alencar e, depois, em outra montagem, pela companhia de Ítalo Cúrcio, dois representantes clássicos do tipo de atividade teatral que os jovens renovadores do teatro nacional desejavam extinguir. Ele próprio, em 1955, dirigiu uma exitosa montagem de sua peça A grande estiagem para a Companhia Teatro Pernambucano, do ator-empresário Elpídio Câmara.

Como Hermilo, embora também muito sintonizado com as novas tendências 
estéticas em voga no exterior, Isaac reconhecia a importância dos velhos fazedores de teatro do país. Ele, certamente, enxergava beleza e poesia na forma como esse teatro tradicional, a despeito de suas precariedades artísticas, conseguia se comunicar com as massas, que lotavam as plateias em busca de diversão; Hermilo também. Ambos, por sinal, sabiam da importância - e da dificuldade - de se ter uma plateia cheia; ambos, em alguns momentos de suas carreiras artísticas, entenderam que, eventualmente, talvez fosse oportuna certa aproximação com as poéticas mais assentadas no gosto médio dos públicos, negando o corte radical com os traços do velho teatro, como pregavam vários dos conjuntos não profissionais mais arrojados, que praticamente encaravam o sucesso de público como uma invariável concessão à mediocridade artística.

Embora tenham os dois, Isaac e Hermilo, efetivado parte significativa de suas atividades teatrais com grupos amadores, quase sempre sem cobrar ingressos, ou cobrando ingressos a preços populares, eles igualmente defendiam o profissionalismo teatral, reconhecendo que a profissão do artista de teatro deveria ser respeitada e valorizada. Todavia, nas ocasiões em que se propuseram a fazer espetáculos para espectadores das classes mais favorecidas da sociedade, tentaram operar em um teatro profissional que fosse capaz de transcender a mera função de entretenimento; trabalharam sempre por um teatro moderno, autoral, buscando oferecer a esse público um “divertimento inteligente" e com "valor artístico". Tal intento se verifica, de modo mais claro, por exemplo, em peças como Um paroquiano inevitável (1952), de Hermilo, e A hora marcada (1955), de Isaac - ambas, curiosamente, inserindo elementos do insólito, aspectos sobrenaturais, em narrativas predominantemente realistas, dramáticas (JARDIM, 2015), a fim de expor preconceitos e hipocrisias muito presentes na sociedade pernambucana. Tal determinação de oferecer à burguesia recifense um teatro de qualidade, com peças capazes de gerar alguma reflexão, também fica clara nas ações de empreendimento teatral capitaneadas pelo dois dramaturgos: assim fez Hermilo, quando foi sócio do Teatro de Arena do Recife, e assim fez Isaac, quando liderou o grupo Os Artistas Unidos, ambas iniciativas vividas com relativo êxito comercial e artístico na primeira metade da década de 1960, no Recife. 


\subsection{Formas e conteúdos}

Tanto Hermilo quanto Isaac passam, ao longo de suas trajetórias, por mudanças significativas no modo como criam suas dramaturgias. Desde os primeiros trabalhos, contudo, ambos evidenciam um inequívoco alinhamento com as orientações do teatro moderno, isto é, o teatro da encenação. Mesmo nas suas peças de juventude, que nem sempre são as suas obras mais instigantes, nota-se um claro propósito de romper com os esquemas consagrados na cena nacional de então.

Um primeiro traço que denota esse compromisso com o novo, talvez seja o esforço por dar aos personagens uma maior profundidade psicológica ou filosófica, na tentativa de fugir dos clichês de personagens-tipo: vilão, mocinho, ingênua, caricata etc. Muito embora, por vezes, essa determinação resultasse em obras um tanto sentenciosas, ou demasiadamente cerebrais, sacrificando um pouco do frescor e da espontaneidade vital das figuras postas em cena, e assim, inopinadamente, se reaproximando das chamadas "peças de tese", quase sempre de pouco apelo teatral, que nunca deixaram de povoar os teatros nacionais, desde a segunda metade do século 19.

No entanto, mesmo quando se percebe certa instrumentalização da cena, em prol da exposição (ou da transmissão) de valores e de crenças supostamente edificantes, ambos os dramaturgos, ainda na juventude, já procuravam se afastar dos modelos formais corriqueiros nos palcos de então. E, para isso, buscam uma aproximação com as correntes vanguardistas que, já há anos, revigoravam o teatro europeu e norteamericano, como o expressionismo, sobretudo em Hermilo, e como certos traços mais triviais do simbolismo, sobretudo em Isaac. Isso se nota, por exemplo, em peças como Conflito na consciência (1950), de Isaac, e Electra no circo (1944), de Hermilo. Essas são obras, porém, em que "os andaimes do edifício" poético, ou melhor, os alicerces dos modelos que inspiraram a construção, ficam ainda demasiada e impensadamente expostos. Hermilo revela-se claramente impactado por Eugene O’Neill (1888-1953); Isaac revisita uma poética trabalhada pelo autor paulista Paulo Gonçalves (1897-1927) na sua famosa Comédia do coração (1927), encenada com sucesso no Recife, em 1944, pelo 
Teatro de Amadores de Pernambuco (TAP), com direção de Zygmunt Turkow (18961970). E são, acima de tudo, obras que evidenciam como ambos estavam ainda fortemente impactados pela exuberante dramaturgia apresentada por Nelson Rodrigues até então, especialmente em Vestido de noiva (1943), com sua altamente teatral exploração psicanalítica das personagens - embora Nelson tenha sempre negado filiação às ideias de Freud.

Em seu livro Lendo Hermilo Borba Filho (1986), a pesquisadora Sônia Maria van Dijck Lima, assim apresenta a peça Electra no circo:

[...] o reino de Micenas é substituído por um circo, cujo espetáculo costumeiro cede lugar para o desenrolar do drama particular dos artistas do circo/personagens [...]. No terceiro e último ato, o autor recorreu a dois planos cênicos a fim de mostrar na atualidade a permanência do conflito primordial. O Rapaz do Trapézio, enlouquecido, alcança compreender as motivações da Moça do Arame/Electra. Mas a peça não toma o caminho psicanalítico e limitase ao registro dos dados que o leitor/espectador pode utilizar para a leitura (LIMA, 1986, p. 20).

Isaac, por sua vez, em Conflito na consciência, cria uma ambiência cenográfica um tanto etérea, onde materializa personagens alegóricos (como Inteligência, Desejo, Realidade, Amor, entre outros), que vão dialogar entre si, sempre falando sobre "Ela", figura que não aparece em cena, mas que é apresentada como "A dona da consciência". Vejamos o trecho inicial do segundo ato:

Ao abrir-se o velário estão em cena os mesmos personagens e nas mesmas posições do fim do primeiro ato: todos voltados para a arcada da D., cuja luz está apagada, enquanto SOFRIMENTO vem descendo a escada. A cena está mergulhada na penumbra.

SOFRIMENTO

- Ela já não sofre... (Chega ao pé da escada)

INTELIGÊNCIA

- Ela desmaiou! Ela desmaiou... (Volta-se e atravessando a cena vai sentar-se em um dos cubos da E.) Foram em vão todos os nossos esforços... (Desmancha-se o quadro, saindo cada um de sua posição) Perdemos o contato com a vida...

VONTADE

- (Aproximando-se de INTELIGENNCIA) E que vais fazer, Inteligência? INTELIGÊNCIA

- Esperar... (GONDIM FILHO, 1951, p. 61).

Hermilo, todavia, diferentemente de Isaac, cedo vai desenvolver um interesse 
pela cultura popular nordestina, notadamente pelos espetáculos dramáticos do povo de nossa região. E isso, não demora, passa a influenciar toda a sua criação teatral, instigando-o na luta por uma nova expressão dramática brasileira, nordestina. Primeiramente, isso se verifica no que diz respeito aos conteúdos, às temáticas abordadas em suas peças, nas quais ele passa a tentar aproveitar teatralmente as histórias e as lendas do Nordeste. Mas, em seguida, esse olhar sobre a cultura do povo vai suscitar nele a compreensão de que era necessária uma mudança também na forma, a fim de que esses novos conteúdos chegassem aos palcos com toda a sua força poética e política. Tal percepção vai moldar a melhor dramaturgia de Hermilo, aquela produzida na maturidade, quando ele já demonstra a necessária desenvoltura para equalizar a contento, e de modo muito original, forma e conteúdo, em obras como A donzela Joana, de 1964, O bom samaritano, de 1965, e Sobrados e Mocambos, de 1972 (BORBA FILHO, 2007).

Isaac, por sua vez, apesar de tratar de temas da terra, como a seca, a miséria (rural e urbana), os preconceitos e as injustiças sociais na sociedade pernambucana etc., o faz, quase sempre, por meio de uma dramaturgia fortemente europeia em sua carpintaria, experimentando eventualmente algo da expressão simbolista, como vimos acima, mas alimentando-se regularmente da poética realista. Isso fica patente, por exemplo, em $A$ grande estiagem (1953) que conta, numa dramática rigorosa - com começo, meio e fim, somente por meio de diálogos - o sofrimento de uma família de miseráveis camponeses que habitam o árido Sertão Nordestino. Esse mesmo apego ao encadeamento dramático da narrativa, criando uma ilusão de mundo autônomo para o desenvolvimento da fábula, fica particularmente saliente em A hora marcada (1955), tida pelo autor como "uma peça de tempo", mas também pode ser encontrado, embora às vezes de modo menos ostensivo, em praticamente todas as peças que escreveu. Tal característica, de uma conformidade estrutural com a literatura dramática europeia mais hegemônica - e mais mediana -, isto é, menos surpreendente e menos autoral, somente vai começar a se modificar nas peças religiosas que Isaac escreve na maturidade. Ali, como se pode notar no seu Drama do evangelho (1982), há uma franca procura por formas mais inventivas de construir a cena, indo em direção ao épico, saudavelmente desrespeitando as diretrizes do ordenamento dramático mais tradicional, propondo soluções despojadas e 
anti-ilusionistas, distribuindo as palavras dos Evangelhos entre personagens, coros e narradores. Assim começa a peça:

\section{Cena 1. A NARRATIVA BEM ORDENADA}

A VOCÊ QUE BUSCA A DEUS - Lc 1,14

LUCAS - (Diante de uma estante ou mesa cheia de livros, folheando algum, pausadamente) - Visto que muitos já tentaram compor a narração dos acontecimentos que entre nós se realizaram, (Entre parênteses, explicativo) como nos foram transmitidos pelos que, desde o princípio, são testemunhas oculares e ministros da palavra... (Caminha à frente, encara os assistentes, salientando bem a ideia do que fala) - A mim, também pareceu conveniente, depois de ter investigado diligentemente todas as coisas, desde o princípio, escrever uma narrativa bem ordenada, para Você que busca a deus... (Faz um gesto oferecendo o seu livro aos assistentes) - ...para que conheça a verdade daquelas coisas em que foi instruído. (Música para terminar) (GONDIM FILHO, 1982, p. 19).

É preciso, porém, ponderar que a própria tradição, ainda europeia, do teatro religioso está fundada em poéticas medievais em que o épico e o anti-ilusionismo sempre estiveram muito presentes. Mesmo assim, não se pode negar que no teatro evangelizador de Isaac exista uma evidente originalidade, distinguindo-se na agilidade das cenas e na criatividade das soluções encontradas, de todo um padrão já muito bem assentado para o gênero. Por exemplo, Isaac é enfático na recomendação de que vestimentas de época não sejam usadas, mas sim "as próprias roupas” que os intérpretes trajam no dia-a-dia, além de sugerir que sejam escolhidas músicas bem conhecidas do "cancioneiro popular ou folclórico" para compor a trilha sonora do espetáculo, lembrando que os espectadores devem ser convidados a cantá-las com os atores, como numa celebração religiosa.

\subsection{Encenação, dramaturgia e engajamento}

Hermilo e Isaac tinham muito em comum, como de certo modo já ficou claro neste ensaio. Todavia, embora tenham sido contemporâneos na cena teatral recifense e tenham sido colegas na antiga Escola de Belas Artes, como docentes do Curso de Teatro da Universidade do Recife, eles jamais trabalharam juntos em projetos artísticos, como 
na criação de algum espetáculo, por exemplo. Respeitavam-se e admiravam-se, mas certamente não havia, entre eles, aquela sutil e um tanto indizível afinidade que une artistas, transformando-os em parceiros fraternos na busca por uma expressão artística compartilhada, a despeito até de possíveis diferenças ideológicas.

Os dois eram, essencialmente, encenadores e dramaturgos. Jamais, porém, um deles encenou uma peça escrita pelo outro. Ou melhor, em 1967, dirigindo seus alunos da Escola de Belas Artes, Isaac incluiu uma cena da peça de Hermilo, A barca de ouro (1947), no espetáculo pedagógico intitulado Autores brasileiros. E nada mais que isso. Hermilo, por sua vez, que tanto valorizava os dramaturgos da terra, não se deteve, como crítico ou como professor, de maneira mais aprofundada sobre o teatro de Isaac. Nem mesmo se interessou em refletir sobre $A$ grande estiagem, ganhadora da Medalha de Prata, no I Festival Brasileiro de Teatro Amador, no Rio de Janeiro, em 1957, o mesmo evento em que o Auto da Compadecida (1956), de Ariano Suassuna, conquistou a Medalha de Ouro, consagrando-se, prontamente, como um marco na dramaturgia nacional, e de certo modo coroando o esforço artístico e intelectual de Hermilo, mentor de Ariano no teatro, que desde meados da década anterior estimulava toda uma geração de novos autores teatrais a enfocarem, numa abordagem moderna, os temas e as questões do Nordeste, de Pernambuco.

Ora, seria natural que Hermilo festejasse um momento tão potente para a dramaturgia pernambucana, com duas obras premiadas no alto do pódio de um festival nacional de muita visibilidade. Mas, aparentemente, ele não se empolga com a conquista de Isaac. À medida que seguirá divulgando enfaticamente, a cada oportunidade que tinha, a genialidade de Suassuna, de quem encenará várias peças, não somente a Compadecida, na primeira montagem profissional desse texto, em São Paulo, no mesmo ano de 1957, mas também, O casamento suspeitoso, em 1958, A pena e a lei, em 1960, Farsa da boa preguiça, em 1961 e em 1969, A caseira e a Catarina, em 1962 e em 1975, Hermilo se cala sobre o êxito de $A$ grande estiagem, aparentemente indiferente ao fato de que a peça, propondo-se como uma tragédia moderna (a rigor, no subtítulo, é classificada como uma "tragédia rural nordestina") - gênero que, como dramaturgo, o próprio Hermilo tanto explorou e enalteceu - ganhava crescente reconhecimento, até mesmo fora do país, recebendo traduções para diversos idiomas; e aparentemente 
relevando o fato de que essa peça cumpria muito bem um dos principais lemas que nortearam o projeto renovador preconizado pelo jovem Hermilo, ao aproveitar dramaturgicamente um problema de enorme gravidade para o Nordeste: o sofrimento causado pela seca aos camponeses miseráveis que insistem, por falta de opção, em habitar o Sertão Nordestino.

Bem antes disso, em sua coluna no jornal Folha da Manhã de 28/6/1949, ao abordar a estreia do Teatro Experimental do Recife, grupo fundado e liderado por Isaac, Hermilo apontou diversas fragilidades artísticas na montagem de $A$ tempestade, de Mário Brasini, a começar pela própria escolha do texto, para ele, repleto de "deficiências"; reprovando também as interpretações, incapazes de "explorar a emoção das frases"; e chegando à cenografia, "uma armação neutra e sem verdade". Entretanto o foco da crítica recaiu mesmo sobre a direção, considerada em tudo "muito primária". Apesar de todas as observações negativas sobre o espetáculo, Hermilo saúda a criação de um novo grupo, destacando a importância dessa iniciativa para "a difusão da arte dramática em nosso estado". Mas pondera que estreantes "têm tanta responsabilidade diante do público quanto os atores mais experimentados".

Embora a diferença de idade entre eles não fosse tão significativa, havia, sim, uma grande diferença, de tempo e de intensidade, quanto ao tipo de envolvimento que cada um tinha, até então, com a arte teatral. Hermilo, que iniciara sua vida nos palcos ainda durante a adolescência, em Palmares - PE, trabalhou no Grupo Gente Nossa, no Recife, onde conviveu com algumas das pessoas mais importantes do teatro na região, tais como, entre outros, Samuel Campelo, Elpídio Câmara, Barreto Júnior, Hermógenes Viana e Valdemar de Oliveira. De lá, seguiu para o TAP, onde amadureceu a sua identidade própria, negando a visão elitista defendida por Valdemar de Oliveira (CADENGUE, 2010). Quando Isaac começa a despontar na cena recifense, Hermilo já era um nome de grande repercussão, estando à frente do TEP desde 1946, capitaneando, com esse conjunto, toda uma ativa movimentação em busca por um novo teatro, moderno como o dos grandes autores-encenadores europeus, mas sintonizado poética e politicamente com as questões da terra, da região; e mais, um teatro que chegasse a todas as camadas da sociedade, e não apenas a setores das classes mais favorecidas. E Isaac, certamente, reconhecia a importância de Hermilo para a atividade teatral da região. Em sua coluna 
no Jornal do Commercio, no dia 03/2/1951, ele noticia a nomeação do "teatrólogo" Hermilo Borba Filho como Secretário da Prefeitura Municipal do Recife, pelo prefeito Antônio Pereira, situando Hermilo como representante "da nova geração intelectual de nossa cidade", reconhecendo-o como um "elemento dos mais ativos entre os impulsionadores do movimento amadorista”. Ele, tampouco, reagiu à crítica negativa produzida por Hermilo em relação ao trabalho de estreia do seu grupo teatral, em 1949, evitando polêmica, certamente assinalando, desse modo, o seu respeito à opinião do crítico.

Isaac, ao longo de toda a sua vida no teatro, encenou muitas das peças que escreveu - mais de dez delas, e algumas delas por diversas vezes. Hermilo, diferentemente, parecia evitar ser o encenador de seus próprios textos. No TEP, em anos de intensa produção dramatúrgica, ele não dirigiu nenhuma peça sua. No Teatro Popular do Nordeste (TPN), fase de grande maturidade artística e, também, de expressiva atividade como autor teatral, ele encenou apenas um texto seu, A bomba da paz (1962), e em circunstância excepcional como veremos logo adiante. Nesses dois grupos, dos quais foi diretor artístico, Hermilo convidou outros encenadores para montar peças suas: o colombiano Henrique Buenaventura, em 1952, dirigiu, para o TEP, Três cavalheiros a rigor; e, em 1966, para o TPN, o mineiro Rubens Teixeira dirigiu O cabo fanfarrão (REIS, 2018).

Contudo, esteticamente, acreditamos que a principal, e talvez decisiva diferença entre os dois autores recaia, como já vimos, no apego formal de Isaac a uma dramática mais tradicional, isto é, a uma escrita teatral mais aristotélica, com unidade de lugar, de tempo e de ação, tudo se revelando diante dos espectadores, mas como se ali não houvesse espectadores. Foi contra tal poética, bem apropriada para espetáculos de ambição realista, calcada numa exposição racional das ações, que se levantaram muitos dos autores mais ousados e instigantes a partir de meados do século 20. O nome de Bertolt Brecht (1898-1956), com sua defesa de um “teatro épico" e “anti-ilusionista”, é central nessa tendência. Mas também, por outro caminho, as propostas de Antonin Artaud (1896-1948), que sugeriam uma verdadeira implosão da racionalidade expressa pelas palavras.

Hermilo, como ele afirma no seu ensaio Diálogo do encenador (BORBA FILHO, 
2005 [1964]), foi um leitor muito atento dos escritos teóricos e artísticos de Brecht e de Artaud, embora sempre creditasse aos mestres da cultura popular nordestina o seu entendimento de que o teatro precisa ser livre, inventivo, crítico, festivo, poeticamente arbitrário, sem pretender replicar a vida, mas se reconhecendo como uma manifestação própria da vida, em um ato de comunhão entre artistas e espectadores. Disso tudo, em alguma medida, talvez Isaac somente tenha se aproximado em suas peças religiosas, boa parte delas escritas e encenadas após a morte de Hermilo. Portanto, ao demonstrar pouca disposição para interpelar as formas dramáticas mais tradicionais, Isaac se afastava das vertentes criativas que começam a ser valorizadas e defendidas por Hermilo desde os tempos do TEP e que, depois, se tornam uma verdadeira prioridade artística, sobretudo a partir de 1958, quando ele retorna de São Paulo, onde por mais de cinco anos atuou como crítico teatral e como encenador. Provavelmente, o fato de Isaac, como dramaturgo, não ser tratado por Hermilo como um discípulo, nem sequer, às vezes, como um companheiro de missão.

Pelo lado menos estritamente ligado à estética teatral, mas sem deixar de dialogar com ela, parece lícito notar diferenças entre Isaac e Hermilo no que diz respeito à visão que cada um tinha sobre complexa relação entre arte e política. E nesse âmbito as divergências, entre eles, tornam-se ainda mais tênues, embora significativas. Ambos entendiam o teatro como um espaço para tratar de temas relevantes ao ser humano e, por conseguinte, à sociedade. Nenhum dos dois se dedicou a um teatro de mera instrumentalização político-partidária, isto é, não aprovavam espetáculos cuja primordial motivação fosse a de passar à plateia alguma mensagem voltada para um direcionamento político específico, ao sacrifício, muitas vezes, da função poética propriamente dita, a que caracteriza, antes de tudo, os atos de criação artística.

Isaac certamente escreveu e dirigiu peças que se justificavam, antes de tudo, como instrumentos de evangelização católica; mas mesmo nesse viés de sua atividade dramatúrgica pode-se notar uma constante preocupação com o aspecto artístico desse teatro, distanciando-se, pela busca de uma originalidade cênica, pelo seu traço autoral, do tipo de peças comumente apresentadas em igrejas e em escolas religiosas. Ele, todavia, jamais escreveu textos teatrais com a intenção de favorecer este ou aquele movimento político-partidário. Há conteúdos políticos e de crítica social em suas peças? Sim. 
Embora nem sempre de modo muito explícito, seus textos colocam sobre o palco problemas graves da sociedade pernambucana, como, por exemplo, a questão das crianças em situação de rua, na tragicomédia $A$ vida continua amanhã (1952), ou o tema do vazio espiritual e da hipocrisia moral da burguesia recifense, em $A$ hora marcada (1955). É reforçando sua crítica à exploração do trabalho infantil que ele conclui o último ato de $A$ vida continua amanhã:

\footnotetext{
(Ouve-se o cocoricar de um galo da vizinhança uma, duas, três vezes)

VITORINO - (Vai despertando lentamente, pouco a pouco. Desnorteado. Levanta-se à custo. Dá-se conta do que aconteceu) Onde é que se meteram os vagabundos? (Corre ao quarto, olha para dentro, nada. Corre à esquerda baixa, desaparece gritando, chamando) Maneco! Maneco!... Zé Maria! Gato! João Preto! Zé Maria! (Vai reentrando desanimado, cansado) Seu Vitorino! MALAQUIAS - (Do outro lado do muro, ao fundo, sem aparecer) VITORINO - Bom dia seu Malaquias!

MALAQUIAS- Alguma novidade por aí? Eu ouvi uns barulhos... VITORINO - (Indo até o fundo, sobe na tina e olha para o outro lado) Ah! Nem queira saber... Os meninos me deixaram, fugiram...

MALAQUIAS - Todos?!

VITORINO - Todinhos... (Noutro tom) Será que o senhor conhece algum menino que queira vender amendoim?

MALAQUIAS - Eu acho que eu sei de um... É do interior, Não tem pai nem mãe. Tá precisando.

VITORINO - Então, mande ele falar comigo. O senhor sabe, não é? O negócio não pode parar, tem que ir pra frente... (GONDIM FILHO, 1952, p. 25)
}

O dramaturgo Hermilo Borba Filho quase sempre agiu de modo semelhante. À exceção da peça $A$ bomba da paz (1962), que foi escrita com o particular objetivo de criticar a situação política no Recife dos primeiros anos da década de 1960, notadamente com intuito de atacar os artistas e os intelectuais que atuavam no Movimento de Cultura Popular (MCP), Hermilo trazia à cena, em suas obras, questões importantes para o entendimento das contradições sociais da região e do país, mas se mantinha bem distante de qualquer arte panfletária. Em diversas ocasiões, ele veio a público manifestar o seu arrependimento por ter escrito e encenado $A$ bomba da paz, reconhecendo-a como um equívoco, como um gesto irrefletido, motivado por raiva pessoal (REIS, 2009). No campo da religiosidade, embora tenha, na maturidade, se aproximado intensamente da 
Igreja Católica, ele não se dedicou propriamente ao teatro de evangelização, apesar de que um dos seus últimos projetos como encenador, o qual não viveu para realizar, tenha sido a montagem do auto sacramental $O$ grande teatro do mundo, de Calderón de la Barca (160o-81), que seria realizada ao ar livre, na frente de Sé de Olinda. Uma peça escrita para evangelizar, mas que, dadas as suas qualidades poético-filosóficas, foi alçada ao cânone do teatro ocidental, tornando-se uma obra clássica. Entretanto, diferentemente de Isaac, Hermilo se fez uma personalidade política de destaque na cena cultural pernambucana, estando sempre envolvido em polêmicas, colocando-se no centro dos debates, levantando bandeiras e cobrando posicionamentos das autoridades. Isaac, embora tenha sido sempre um homem de convicções sólidas, não demonstrava disposição para esse tipo de atuação. Sua política era a sua arte e o seu trabalho como criador e como professor de teatro.

Um outro aspecto, de certo modo também ligado à religião, parece, entretanto, distinguir ainda mais significativamente os dois autores em questão. Embora ambos tenham sido católicos de grande fé, Hermilo não pautava suas peças pelos pressupostos morais do catolicismo. Já no teatro de Isaac, temas como adultério e aborto, ou perda de virgindade antes do casamento, são quase sempre tratados pela ótica do catolicismo, deixando transparecer com nitidez o sistema de valores do dramaturgo. Isso fica muito evidente, por exemplo, em peças como A hora marcada (1955), Tara (1952), e Via Margutta, Roma (1964). Na nota de apresentação da peça Conflito na consciência, publicada, como livro, em 1951, pela Folha da Manhã, o pai de Isaac diz que o texto escrito e encenado por seu filho ressalta "como lição proveitosa, o tema de que uma educação e disciplina severas acautelam o homem contra conflitos e torturas morais (...). O homem, necessariamente, será protegido contra esses conflitos se não transgredir princípios de moral e de religião" (GONDIM FILHO, 1951, p.5). Por exemplo, nas últimas cenas de $A$ hora marcada, quando Catarina, a esposa de Pedro, descobre que o marido, médico, ganhara muito dinheiro praticando abortos clandestinos, ela o ofende verbalmente, acionando uma retórica conhecida nos meios católicos menos ponderados:

PEDRO - (Depois de breve pausa) Não foi a primeira vez, nem foi a também foi a última. É uma coisa para a qual muita gente procura os médicos... Pagam bem, muito bem mesmo! Por sua vez, podemos exigir... Dá dinheiro. 
EMÍLIA- Dr. Pedro...!

CATARINA- Então você era acostumado a fazer isso?

PEDRO- Bobinha! E a nossa fortuna? As regalias que temos tido? As viagens que temos feito? A vida que levamos?

CATARINA- Então, Pedro...? Todo o nosso dinheiro vem destas coisas...? Você é mesmo um homem assim...? Sem escrúpulos? Um assassino profissional?

PEDRO- (Aproximando-se) Mas, Catarina...

CATARINA- Não me toque! Eu tenho horror a você! Nojo! Um assassino de pequeninas vítimas inocentes! Desgraçado! Miserável! (GONDIM FILHO, 1955, p.6o).

Embora a correção moral da personagem Catarina seja também posta em xeque, quando o marido, na frente dos amigos, lembra que ela sempre gostou muito do dinheiro, que ele conseguia gerar em sua prática ilícita, dando a entender que ela era, de certo modo, conivente, ao não se preocupar muito em saber se aqueles recursos eram obtidos de forma honesta; o que prevalece, no todo da peça, é mesmo o ethos católico, tratando o aborto, indiscutivelmente, como um pecado mortal. Ou seja, a peça critica a hipocrisia dos personagens, espelhando a hipocrisia existente na sociedade, mas não põe em perspectiva a inaceitabilidade do aborto - posicionamento inegociável na fé católica. $\mathrm{Na}$ dramaturgia de Hermilo, a moral das peças não se plasma, assim, tão diretamente, pela crença religiosa do autor. Em Auto da mula de padre (1948), por exemplo, a "mulata" que se fez amante do Padre é punida, conforme o imaginário popular, transformando-se em mula. Mas isso, no texto, não aparece simplesmente como um castigo celestial. Pelo contrário, no modo como as ações se apresentam, o espectador/leitor fica a se perguntar sobre a validade dos costumes daquela sociedade tão permeada de hipocrisia e de iniquidade.

\section{Síntese à luz do Regionalismo}

Isaac Gondim Filho e Hermilo Borba Filho deram, cada um a seu modo, importantes contribuições para a modernização do teatro em Pernambuco na segunda metade do século 2o. Um olhar sobre as obras criadas por esses dois homens de teatro evidencia que, apesar de terem opções poéticas nem sempre coincidentes, 
compartilhavam da convicção de que era possível, e necessário, fazer do teatro um espaço propício a uma genuína expressão artística, francamente autoral, transcendendo o objetivo de apenas entreter os espectadores, tal como acontecia, quase sempre, no teatro praticado até a então.

Como artistas e intelectuais atuantes fora dos maiores centros culturais, e vivendo em um país caracterizado pelas duras contradições do seu recente passado colonial, interpelaram certo entendimento mais limitado - e mais limitador - daquilo que poderia ser chamado de um "teatro brasileiro". Foram homens de ação, que se fizeram protagonistas na busca por inserir a cena pernambucana nas discussões sobre as tendências que (re)configuravam a atividade teatral no país, sobretudo a partir da década de 1940.

Tanto Isaac quanto Hermilo trabalharam intensamente ao longo de toda a vida, quase nunca dispondo de um apropriado amparo econômico para as suas realizações. A paixão pela criação teatral, muitas vezes, suplantava as dificuldades de produzir, amadoristicamente, espetáculos ambiciosos em suas concepções, mas em geral de pouco apelo comercial. Mesmo assim, movimentaram os palcos recifenses com peças que, independentemente de obterem maior ou menor reconhecimento artístico-técnico, tinham um evidente compromisso com o novo, causando um saudável estranhamento nos espectadores, fazendo-os entrar em contato com poéticas desconhecidas por quem era afeito às chanchadas e aos dramalhões que frequentemente ocupavam as casas de espetáculo da região.

Apesar de não terem feito parte dos grupos intelectuais mais diretamente ligados a Gilberto Freyre, Hermilo e Isaac deram vida, no âmbito do fazer teatral, ao cerne das proposições regionalistas que, desde 1926, vinham formando uma espécie de "espírito da época" na vida cultural recifense: a desafiadora equação envolvendo Região, Tradição e Modernidade. Todavia, sem serem Regionalistas dogmáticos, presos a prescrições, cada um deles interpretou essas variáveis de forma própria, e decerto um tanto intuitivamente. Mesmo sabendo que, na concepção Regionalista de Freyre, proposta como uma espécie de "processo civilizatório", esses termos - Região, Tradição e Modernidade - não se separam, pois se interpenetram e se modificam constantemente (VIEIRA, 2006), eles serão aqui abordados um a um apenas para guiar mais claramente 
esta síntese das semelhanças e das diferenças entre os dois dramaturgos em tela.

"Região", para o jovem Hermilo, significava levar aos palcos temáticas da cultura local. Com o passar dos anos, porém, isso já não lhe parecida suficiente: era preciso buscar uma forma, e não apenas conteúdos que tivesse inspiração na alma do povo nordestino. E, para isso, no entendimento dele, o melhor caminho seria o diálogo com espetáculos populares, como o bumba-meu-boi, o mamulengo e o pastoril. Isaac, por sua vez, também se preocupou em trazer aos palcos os problemas típicos da região, mas os apresentando dentro de formatos dramatúrgicos mais estabelecidos, ou mais hegemônicos, em geral com peças de forte estrutura dramática e de franca fisionomia realista.

Quanto à "Tradição", olhando-os por certo aspecto desse termo, os dois dramaturgos pareciam reconhecer e valorizar a experiência de artistas teatrais que, com a chegada do teatro moderno, passaram a ser desprezados pelos grupos mais vanguardistas, e supostamente mais intelectualizados. Isaac e Hermilo, mesmo sabendose distintos dessas práticas que, há muitas décadas caracterizavam o grosso do fazer teatral profissional no Brasil, foram capazes, em alguns momentos, de interagir positivamente com esse tipo de teatro tido como "ultrapassado" pelos jovens amadores mais "modernos". Ambos, também, como autores, mostravam-se reverentes à grande tradição da dramaturgia ocidental, na qual, claramente, procuravam se inserir. Já por outro aspecto da ideia de “Tradição", para além do teatro, podemos pensar que, para Hermilo, mas não para Isaac, a cultura popular, com suas histórias e com suas formas, com suas cores e com suas dinâmicas, se apresentava como o local por excelência onde estariam guardadas as mais significativas tradições de uma nação.

No que diz respeito à "Modernidade", conceito dos mais amplos, e absolutamente central na história da humanidade, desde o final da Idade Média, quando a religião foi separada das demais áreas do saber humano, faremos aqui um recorte bem específico. A ideia de modernidade está associada, também, desde o início, ao desenvolvimento das tecnologias de transporte e de comunicação, dando ao ser humano uma maior capacidade de deslocamento geográfico e de conhecimento de diversas culturas, de diversos modos de vida. Ser moderno, portanto, é saber o que se faz em outras sociedades, e também se fazer notado por outras sociedades. Modernidade, por esse viés, 
se associa ao cosmopolitismo, e as cidades, sobretudo os maiores centros urbanos, seriam, por essência, o lugar para onde naturalmente afluiriam as novidades produzidas por diversas culturas. Assim, poder transitar, poder conhecer e ser conhecido pela cultura das grandes cidades, dos circuitos mais cosmopolitas, é uma aspiração marcadamente moderna.

Esse aspecto da modernidade parece oportuno para abordarmos, aqui, uma última, e bem relevante, diferença entre Isaac Gondim Filho e Hermilo Borba Filho. Percebemos, no conjunto da obra dramatúrgica de Hermilo, uma mudança muito clara após os anos em que ele viveu em São Paulo, durante a década de 1950. Ali, como crítico teatral, acompanhou intensamente toda a produção cênica que se apresentava na maior e mais rica cidade do país, que passava a reivindicar uma hegemonia no campo cultura, até então dominado pelo Rio de Janeiro. Foram anos de apogeu do Teatro Brasileiro de Comédia (TBC), do italiano Franco Zampari. Esse empreendimento se propunha a fazer no Brasil um teatro "tão bom quanto" o melhor do teatro moderno europeu. Como método, importavam-se competentes encenadores estrangeiros, que eram encarregados de montar, quase sempre, obras de autores também estrangeiros - ou de brasileiros que, em grande medida, emulavam tais autores estrangeiros. Intercalando obras de real valor artístico com textos mais comerciais, os espetáculos do TBC, muito calcados numa estética realista, agradavam à elite paulista, pela qualidade técnica e pelo carisma do talentoso elenco de atores e atrizes brasileiros que ali trabalhavam, e que logo se consolidam como as grandes estrelas da cena nacional moderna (GUZIK, 1986). Aquele fazer teatral, contudo, não demora a aborrecer Hermilo, criado numa cultura tão rica e diversa como a da Zona da Mata Sul de Pernambuco. Ao retornar ao Recife, em 1958, tudo o que ele queria era se diferenciar do estilo do TBC. Daí o seu mergulho, agora ainda mais intenso e profundo, na cultura popular. Não queria "ser tão bom quanto" o teatro hegemônico europeu. Queria ser diferente: brasileiro, nordestino.

Isaac, por sua vez, até ir estudar na Europa, praticava um teatro que, formalmente, muito parecia perseguir um padrão artístico semelhante ao do TBC. Embora os conteúdos de várias de suas peças talvez não se encaixassem tranquilamente no estilo das produções de Zampari, a dramaturgia, em sua estrutura formal, era bem semelhante à maioria das peças que entretinham a burguesia de São Paulo. Isso, cremos, dificultava 
em muito o endosso de Hermilo às peças de Isaac, colocando-os praticamente como forças estéticas opostas, embora ambos inseridos na luta pelo desenvolvimento de uma cena moderna no Recife. A vivência na Europa, porém, parece ter instado Isaac a repensar sua dramaturgia, que sintomaticamente passa ser produzida com bem menos frequência. Somente nos seus textos religiosos, em especial nos que escreveu durante os anos de 1970 e de 1980, veremos uma liberdade criativa mais potente, mais autônoma, livre dos modelos que, antes, se colocavam, para ele, praticamente como o caminho exclusivo rumo à modernidade teatral. Ali, no seu teatro religioso, Isaac não parecia mais querer ser "tão bom quanto"; demonstrava, isto sim, ser um autor seguro de suas possibilidades, naturalmente original. Uma pena Hermilo, que morreu em 1976, não ter podido acompanhar essa mudança no teatro de Isaac, pois então muito provavelmente ele teria, por fim, aplaudido o colega dramaturgo.

\section{Referências}

BRANDÃO, Tania. Uma empresa e seus segredos: companhia Maria Della Costa. Prefácio de João Roberto Faria. São Paulo: Perspectiva; Rio de Janeiro: Petrobrás, 2009. BORBA FILHO, Hermilo. Hermilo Borba Filho: teatro selecionado. Organizado por Leda Alves e Luís Augusto Reis. Apresentação de Celso Frateschi. Prefácio de Luís Augusto Reis. Três volumes. Rio de Janeiro: Funarte, 2007.

Diálogo do Encenador - Teatro do povo, Mise-en-scène e A donzela Joana. Prefácio Luís Augusto Reis. Recife: Edições Bagaço e Editora Massangana, 2005 [1964]. CADENGUE, Antônio Édson. TAP: sua cena \& sua sombra - o Teatro de Amadores de Pernambuco (1941 - 1991). Prefácio de Sábato Magaldi. Recife: Cepe, 2010.

FARIA, João Roberto. (org.) História do Teatro Brasileiro. Volumes 1 e 2. São Paulo: Perspectiva, 2013.

FREYRE, Gilberto. Movimento Regionalista, Tradicionalista e, a seu modo, Modernista do Recife. In QUINTAS, Fátima (org.) Manifesto Regionalista. $7^{\underline{a}}$ Edição. Prefácio de Antônio Dimas. Recife: Fundaj / Edições Massangana, 1996 [1976]. 
GONDIM FILHO, Isaac. O drama do evangelho. Prefácio de Dom Hélder Câmara. Rio de Janeiro: Editora Vozes, 1982.

. A grande estiagem - tragédia em 3 atos. Rio de Janeiro: SNT, 1973.

. A hora marcada. Cópia datilografada, 1955.

. Conflito na consciência. Recife: Editora da Folha da Manhã, 1951.

. A vida continua amanhã. Cópia datilografada, 1952.

GUZIK, Alberto. TBC: crônica de um sonho. São Paulo: Perspectiva, 1986.

JARDIM, Jéssica C. Diálogos pernambucanos: A hora marcada, de Isaac Gondim Filho. In: Revista aSPAs. Volume 5, número 2, pp. 54-66. São Paulo: USP, 2015.

MILARÉ, Sebastião. A batalha de quimera. Rio de Janeiro: Funarte, 2009.

PONTES, Joel. O Teatro moderno em Pernambuco (2 $2^{\underline{a}}$ edição). Prefácio de Luiz Maurício

Carvalheira. Recife: Fundarpe, 1990 [1966].

PRADO, Décio de Almeida. O teatro brasileiro Moderno. 2 $2^{\mathbf{a}}$ edição. São Paulo: Perspectiva, 1996.

REIS, Luís Augusto. Fora de Cena, no Palco da Modernidade: um Estudo do Pensamento Teatral de Hermilo Borba Filho, 2009.

REIS, Luís. Teatro popular do Nordeste: o palco e o mundo de Hermilo Borba Filho. Recife: Cepe, 2018.

VIEIRA, Anco Márcio T. (org.) Teatro de Luiz Marinho. Volumes 1, 2, 3 e 4. Recife: Cepe, 2019 .

. O projeto civilizatório do Regionalismo. In: Revista Continente Multicultural, Ano VI, № 72, pp. 95-96. Recife: Cepe, 2006.

Recebido em 19/05/2020.

Aprovado em 28/05/2020. 